\title{
Risk Factors of Hamstring Strain in Football Players
}

\author{
Shahid Shafiq ${ }^{1}$, Umer Maqsood ${ }^{2}$, Hafiz Sheraz Arshad ${ }^{3}$ \\ ${ }^{1}$ Physical Therapist, Azra Naheed Medical College, Department of Physical Therapy, Main Raiwind Road,Lahore \\ ${ }^{2}$ Assistant professor, Azra Naheed Medical College, Department of Physical Therapy, Main Raiwind Road,Lahore \\ ${ }^{3}$ Head of Department/Assistant professor, Azra Naheed Medical College, Department of Physical Therapy, Main Raiwind Road,Lahore
}

\begin{abstract}
The objective of this study was to determine the risk factors for hamstring strain in football players. A observational study was conducted among football players of different clubs of Lahore Convenient sampling technique was used. A questionnaire was distributed among 138 players to collect the data. The mean age of hamstring injury that is calculated in this study is 24.62 $\pm 3.477 S D$. The other risk factor are insufficient cool down. 75(54.3\%) out 138 did not perform cool down after the match. 107(77.5\%) were did not stretch after the match. 89(64.5\%) players out of 138 were found with the complaint of fatigue. 52(37.7\%) Respondents had experienced hamstring injury second time. 38(27.5\%) Respondents had experienced hamstring injury third time. The frequency of football players who were defender was $79(52.2 \%)$. The frequency of football players who were striker was $51(37.0 \%) .90(65.2 \%)$ out of 138 players of were found with history of hamstring injury. 24(17.4\%) out of 138 players of football were found with history of back injury. 79(57.2) out of 138 players were found with history of knee injury. 68(49.3\%) out of 138 players were found with a history of groin injury. This study was undertaken to address, the information on risk factors for hamstring strain. Overall, the study identified a number of potential causal relations between baseline factors and hamstring injury. In particular, age, cool down, stretching after match, complaints of fatigue, playing position and previous history of back, hamstring, knee and groin injury were significant risk factors for hamstring strain.
\end{abstract}

Keywords: Back injuries, Football, Hamstring strain, knee injuries, risk factors

\section{Introduction}

\subsection{Overview}

Hamstring injuries are very common in football player. Hamstring injury is usually occur due to late swing and stance phase and this injury is also occur due to lack of muscle flexibility, strength imbalance, lower back injury, insufficient warm-up and poor lumber posture.[1]

Hamstring injury is very frustrating injury because healing process is slow and the rate of reinjury is very high .Hamstring injury common in those player who involved in sprinting and jumping activity. [2]

Different studies have focused on increasing hamstring strength will reduce the chances of hamstring injury one. The aim of different studies to evaluate the effectiveness of different interventions. Hamstring injury are also common in students who have take part in sporting activities. In hamstring muscle the bicep femoris stretch is most common as compare to other hamstring muscles. Running related hamstring injury occur along with an intramuscular tendon or aponeurosis.[3]

In Pakistan many students and athletes are engaged with football and they also face many injuries in sports activity and most common in them is hamstring injury. I am also a football player and sports having a important part in my life so in different player I have seen many deformities regarding hamstring. and I also have many information regarding hamstring injury.so I want to check risk factors of hamstring injury for further information or study because I want to make a long carrier in football. My future plan is also doing further study in sports physiotherapy.
A previous hamstring injury is the most recognized risk factor for injury. A study of elite track and field athletes with acute, first-time, unilateral hamstring muscle strains found that low-grade hamstring muscle injuries may lead to a higher risk of reinjures than high-grade injuries. [4]

Triki et al., 2015conducted research for systemaccepting of the biomechanics of the hamstrings during running is essential to elevate injury restoration and inhibition strategies. The main goals of this study were to relate hamstrings load across different modes of movement as well as before and after an acute sprinting-related muscle strain injury. Hamstrings load was originate to be highest during incurable swing for running. The hamstrings added the commonincurable strike extension of hip and flexion of knee torques.[5]

Engebretsen et al., 2010conducted a research to detect hazard for hamstring damage at the public level of Australian footballer. 126 public level football players take part in this study. A hamstring injury was the 1 st damage of the season with twenty players. Old age greater than 23 years was related with an enlarged risk of hamstring muscle injury.[6]

Silder et al., 2008calculated factors related to recurring hamstring injury. Result shows that the certain of the riskfactors are the most likely ones conforming to insufficient exercises, inacceptable structure \& the training, muscle tension \& faintness, agonist and antagonist inequities, underestimation of widespread damage, use of unsuitable medications, incidence of a widespread scar tissue and, above all, defective or destructive restoration. [7] 


\section{International Journal of Science and Research (IJSR)}

ISSN (Online): 2319-7064

Index Copernicus Value (2013): 6.14 | Impact Factor (2015): 6.391

\subsection{Objective}

To determine the risk factors for hamstring strain in football players.

\subsection{Rationale}

It will be helpful in identifying risk factors of hamstring strain and prevention of risk factors of hamstring strain can improve their quality of life in these football players.

\subsection{Operational definitions}

\subsubsection{Take the shoe-off test}

Take the shoe off test was used to assess hamstring strain in football players. The sensitivity of this test is .55 to 1 and specificity ranges from.03 to 1 . Self-administered questionnaire will be used to determine the risk factors for hamstring strain in football players.[8]

\subsection{Materials and Methods}

\subsubsection{Study design}

Observational study

\subsubsection{Setting}

Data was collected from the different football clubs of Lahore.

- Pak football federation

- MTFC(model town football club)

- Wapda football club

- Pak army football club

1.5.3. Study population

Football players of different clubs of Lahore.

\subsubsection{Duration of study}

The duration of study was 3 months

\subsubsection{Sample size}

A sample size of 138 foot ballers was calculated using the following formula.

$$
\begin{array}{lll}
x & = & \mathrm{Z}\left({ }^{c} / 100\right)^{2} \mathrm{r}(100-\mathrm{r}) \\
n & = & \\
E & = & \left((N-1) E^{2}+x\right) \\
& & \operatorname{Sqrt}\left[{ }^{(N-n) x} / n(N-1)\right]
\end{array}
$$

\subsubsection{Sampling technique}

Convenient sampling was used.

\subsubsection{Eligibility}

\subsubsection{Inclusion criteria}

- Male football players of above mentioned settings

- Age limit 16 to 35 years

- 6month memberships

- Hamstring injury in last 3 months

\subsubsection{Exclusion criteria}

- Metabolic or pathological diseases

\subsubsection{Data collection}

Data was collected from different football players,by performing special (take the shoe-off)test and by the use of self-administrated questioner after the informed consent; all the ethical values were considered.

\subsubsection{Ethical consideration}

There were no ethical issues in this study

\subsubsection{Statistical procedure}

All collected data were entered in computer program SPSS version 17 and analyses through this software. For categorical variable frequency and percentage was used and for discrete variables mean and standard deviation was used.

\section{Results}

Table 1: Descriptive Statistics of Age, weight, height and BMI of participants

\begin{tabular}{|c|c|c|c|}
\hline & Minimum & Maximum & Mean \pm SD \\
\hline Age & 17 & 34 & $24.62 \pm 3.47$ \\
\hline Height & 4.5 & 6.2 & $5.758 \pm 7.97$ \\
\hline Weight & 45 & 95 & $72.275 \pm 7.97$ \\
\hline BMI & 17.6 & 33.4 & $24.340 \pm 2.43$ \\
\hline
\end{tabular}

The Mean age of football players was found to be $24.62 \pm 3.477$ SD with maximum of 34 and minimum of 17 years. The mean height of football players was found to be $5.758 \pm 7.9751 \mathrm{SD}$ with maximum of 6.2 feet and minimum of 4.5 feet. The mean weight of football players was found to be $72.275 \pm 7.9751 \mathrm{SD}$ with maximum of $95 \mathrm{~kg}$ and minimum of $45 \mathrm{~kg}$. The mean BMI of football players was found to be $24.340 \pm 2.4370 \mathrm{SD}$ with maximum of 33.4 and minimum of 17.6 .

Table 2: Warm-up and cool down

\begin{tabular}{|c|c|c|c|}
\hline & & Frequency & Percentage \\
\hline Warm-up & Yes & 132 & 95.7 \\
\cline { 2 - 4 } & No & 6 & 4.3 \\
\hline \multirow{2}{*}{$\begin{array}{c}\text { Cool- } \\
\text { down }\end{array}$} & Yes & 63 & 45.7 \\
\cline { 2 - 4 } & No & 75 & 54.3 \\
\hline
\end{tabular}

Frequency of football players who were doing warm up before match was $132(95.7 \%)$. Frequency of football players who were not doing warm up before the match was $6(4.3 \%)$

Frequency of football players who were doing cool down after match was $63(45.7 \%)$ Frequency of football players who were not doing cool down after the match was $75(54.3 \%)$

Table 3: Stretch before and after match

\begin{tabular}{|c|c|c|c|}
\hline & & Frequency & Percent \\
\hline \multirow{2}{*}{$\begin{array}{c}\text { Stretch } \\
\text { before match }\end{array}$} & Yes & 109 & 79.0 \\
\cline { 2 - 4 } & No & 29 & 21.0 \\
\hline \multirow{2}{*}{$\begin{array}{c}\text { Stretch after } \\
\text { match }\end{array}$} & Yes & 31 & 22.5 \\
\cline { 2 - 4 } & No & 107 & 77.5 \\
\hline
\end{tabular}

Frequency of football players who were doing stretch before match was $109(79.0 \%)$. Frequency of football players who were not doing stretch before the match was 29(21.0\%) 


\section{International Journal of Science and Research (IJSR) \\ ISSN (Online): 2319-7064 \\ Index Copernicus Value (2013): 6.14 | Impact Factor (2015): 6.391}

Frequency of football players who were doing stretch after match was 31(22.5\%). Frequency of football players who were not doing stretch after the match was $107(77.5 \%)$

Table 4: Complaint of fatigue

\begin{tabular}{|c|c|c|}
\hline & Frequency $(\mathrm{n}=138)$ & Percent \\
\hline Yes & 89 & 64.5 \\
\hline No & 49 & 35.5 \\
\hline
\end{tabular}

$89(64.5 \%)$ players out of 138 were found with the complaint of fatigue. 49(35.5\%) out of 138 were found without complaint of fatigue.

Table 5: frequency of injury

\begin{tabular}{|c|c|c|}
\hline & Frequency & Percent \\
\hline $1^{\text {st }}$ & 48 & 34.8 \\
\hline $2^{\text {nd }}$ & 52 & 37.7 \\
\hline $3^{\text {rd }}$ & 38 & 27.5 \\
\hline
\end{tabular}

$48(34.8 \%)$ out of 138 Respondents had experienced hamstring injury first time. 52(37.7\%) Respondents had experienced hamstring injury second time. 38(27.5\%) Respondents had experienced hamstring injury third time.

Table 6: frequency of duration of playing since the participant started playing

\begin{tabular}{|c|c|c|}
\hline & Frequency & Percent \\
\hline 1-2 year & 11 & 8.0 \\
\hline 3-4 year & 14 & 10.1 \\
\hline$>4$ year & 113 & 81.9 \\
\hline
\end{tabular}

$11(8.0 \%)$ out of 138 players were playing from $1-2$ years. $14(10.1)$ out of 138 players were playing from 3-4 years. $113(81.9 \%)$ out of 138 players were playing from more than 4 years.

Table 7: Playing position on ground

\begin{tabular}{|c|c|c|}
\hline & Frequency & Percent \\
\hline Defender & 79 & 52.2 \\
\hline Striker & 51 & 37.0 \\
\hline Goal keeper & 8 & 5.8 \\
\hline
\end{tabular}

The frequency of football players who were defender was $79(52.2 \%)$. The frequency of football players who were striker was $51(37.0 \%)$ The frequency of football players who were goalkeeper was $8(5.8 \%)$

Table 8: Region wise Frequency distribution of History of Injury

\begin{tabular}{|c|c|c|c|}
\hline \multirow{2}{*}{} & & $\begin{array}{c}\text { Frequency } \\
(\mathrm{n}=138)\end{array}$ & Percent \\
\hline \multirow{2}{*}{$\begin{array}{c}\text { History of Hamstring } \\
\text { injury }\end{array}$} & Yes & 90 & 65.2 \\
\cline { 2 - 4 } & No & 48 & 34.8 \\
\hline History of back injury & Yes & 24 & 17.4 \\
\cline { 2 - 4 } & No & 114 & 82.6 \\
\hline \multirow{3}{*}{ History of knee injury } & Yes & 79 & 57.2 \\
\cline { 2 - 4 } & No & 59 & 42.8 \\
\hline \multirow{3}{*}{ History of groin injury } & Yes & 68 & 49.3 \\
\cline { 2 - 4 } & No & 70 & 50.7 \\
\hline \multirow{2}{*}{$\begin{array}{c}\text { History of Calf muscle } \\
\text { strain }\end{array}$} & Yes & 76 & 55.1 \\
\cline { 2 - 4 } & No & 62 & 44.9 \\
\hline
\end{tabular}

$90(65.2 \%)$ out of 138 players of football were found with history of hamstring injury. $24(17.4 \%)$ out of 138 players of football were found with history of back injury. 79(57.2) out of 138 players of football were found with history of knee injury. 68(49.3\%) out of 138 players of football were found with history of groin injury. 76(55.1\%) out of 138 players of football were found with history of calf muscle strain injury.

\section{Discussion}

This observational study was based on 3 months' time period and 138 players were studied. A questionnaire was used for each player, which was filled on the basis of history and presenting complains. The patients were sports professionals of football

According to the results of this study mean age of players had hamstring injury was $24.62 \pm 3.477$. A similar study was performed by Opar et al, they studied that age is common risk factor of hamstring injury. They concluded that older age $>23$ is a risk factor for hamstring strain.[9]

In present study, out of 138 players 89(64.5\%) showed complain of fatigue. A similar study was conducted by Liu et al that indicated fatigue was the risk factor for hamstring injury among male adolescent soccer players.[10]

According to this study $132(95.7 \%)$ out of 138 players were doing warm up before the match and $6(4.3 \%)$ did not and $63(45.7 \%)$ were doing cool down and $75(54.3 \%)$ were not. After the match doing cool down decrease the risk of fatigue and hamstring injury. 107(77.5\%) out 138 were not doing stretch after the match. A similar study was conducted by Croisier to check out the risk factors that contributed to hamstring injury in football players. That study indicated insufficient warm up, cool down and stretching leads to the hamstring strain injury.[11]

In present study $90(65.2 \%)$ out of 138 players were with previous history of hamstring injury. There is greater risk of reoccurrence of hamstring injury. [12]

A similar study was conducted to evaluate the risk factors of hamstring strain injury. This indicated previous history of hamstring strain is a significant risk factor of new hamstring injury. [6]

According to my study defender $79(52.2 \%)$ out of 138 and strikers $51(37.0 \%)$ out 138 experienced hamstring injury and goal keepers $8(5.8 \%)$ out of 138 experienced the hamstring injury. It shows that defender and strikers are at greater risk of hamstring injury. A similar study was heldto evaluate the risk factors of hamstring strain injury. This study indicated that outfield players (defender and strikers) had (22\% 37\%) greater incidence of hamstring strain injury. [12]

According to my study 79(57.2) out of 138 had previous history of knee injury who had experienced hamstring strain injury. 68(49.3\%) out of 138 players of football were found with history of groin injury who had experienced hamstring injury. A study was conducted by Verrall et al indicated previous history of knee injury and groin injuries are the significant risk factors of hamstring strain injury. [13] 


\section{International Journal of Science and Research (IJSR) \\ ISSN (Online): 2319-7064}

Index Copernicus Value (2013): 6.14 | Impact Factor (2015): 6.391

\section{Conclusion}

This study was undertaken to address the information on risk factors for hamstring strain, particularly at the community level where these injuries are both common and costly to clubs and players. Overall, the study identified a number of potential causal relations between baseline factors and hamstring injury. In particular, age, cool down, stretching after match, complaints of fatigue, playing position and previous history of back, hamstring, knee and groin injury were significant risk factors for hamstring strain

\section{References}

[1] BAHR, R. \& HOLME, I. 2003. Risk factors for sports injuries - a methodological approach. British journal of sports medicine, 37, 384-392.

[2] ASKLING, C. M., TENGVAR, M., SAARTOK, T. \& THORSTENSSON, A. 2008. Proximal Hamstring Strains of Stretching Type in Different Sports Injury Situations, Clinical and Magnetic Resonance Imaging Characteristics, and Return to Sport. The American journal of sports medicine, 36, 1799-1804.

[3] BAQUIE, P. \& REID, G. 1999. Management of hamstring pain. Australian family physician, 28, 1269.

[4] GUEX, K. \& MILlET, G. P. 2013. Conceptual framework for strengthening exercises to prevent hamstring strains. Sports Medicine, 43, 1207-1215.

[5] TRIKI, M., KOUBAA, A., MASMOUDI, L., FELLMANN, N. \& TABKA, Z. 2015. Prevalence and risk factors of low back pain among undergraduate students of a sports and physical education institute in Tunisia. Libyan Journal of Medicine, 10.

[6] ENGEBRETSEN, A. H., MYKLEBUST, G., HOLME, I., ENGEBRETSEN, L. \& BAHR, R. 2010. Intrinsic risk factors for hamstring injuries among male soccer players a prospective cohort study. The American Journal of Sports Medicine, 38, 1147-1153.

[7] SILDER, A., HEIDERSCHEIT, B. C., THELEN, D. G., ENRIGHT, T. \& TUITE, M. J. 2008. MR observations of long-term musculotendon remodeling following a hamstring strain injury. Skeletal radiology, 37, 11011109.

[8] REIMAN, M. P., LOUdON, J. K. \& GOODE, A. P. 2013. Diagnostic accuracy of clinical tests for assessment of hamstring injury: a systematic review. journal of orthopaedic \& sports physical therapy, 43, 222-231.

[9] OPAR, M. D. A., WILliams, M. D. \& SHIELD, A. J. 2012. Hamstring strain injuries. Sports medicine, 42, 209-226.

[10]LIU, H., GARRETT, W. E., MOORMAN, C. T. \& YU, B. 2012. Injury rate, mechanism, and risk factors of hamstring strain injuries in sports: A review of the literature. Journal of Sport and Health Science, 1, 92101.

[11]CROISIER, J.-L. 2004. Factors associated with recurrent hamstring injuries. Sports medicine, 34, 681695.

[12]PRIOR, M., GUERIN, M. \& GRIMMER, K. 2009. An evidence-based approach to hamstring strain injury: a systematic review of the literature. Sports Health: A Multidisciplinary Approach, 1, 154-164.
[13] VERRALL, G., SLAVOTINEK, J., BARNES, P., FON, G. \& SPRIGGINS, A. 2001. Clinical risk factors for hamstring muscle strain injury: a prospective study with correlation of injury by magnetic resonance imaging. British Journal of Sports Medicine, 35, 435-439.

\section{Author Profile}

Shahid Shafiq is Physical Therapist, Azra Naheed Medical College, Department of Physical Therapy, Main Raiwind Road, Lahore

Umer Maqsood is Assistant Professor, Azra Naheed Medical College, Department of Physical Therapy, Main Raiwind Road, Lahore

Hafiz Sheraz Arshad is Head of Department/Assistant Professor, Azra Naheed Medical College, Department of Physical Therapy,

Main Raiwind Road, Lahore 